Bangladesh J. Bot. 48(2): 353-358, 2019 (June)

\title{
EXOGENOUSLY APPLIED 5-AMINOLEVULINIC ACID MEDIATED PHYSIOCHEMICAL REGULATIONS AMELIORATE WEAK LIGHT STRESS IN TOBACCO SEEDLINGS
}

\author{
Najia Li ${ }^{1}$, Muhammad Shahid ${ }^{2,3}$, Xuefeng Zong, Jun Lv, Daibin Wang ${ }^{1}$, \\ Amna Saleem ${ }^{4}$, Shakeel Ahmad Anjum ${ }^{2}$ and Sangen Wang* \\ College of Agronomy and Biotechnology, Southwest University, Chongqing 400716, China
}

Keywords: Chlorophyll fluorescence, Membrane stability, Osmo-protectants, Oxidative stress, Photosynthesis, Quantum yield, Stay green

\begin{abstract}
Experiments were conducted to study the deleterious impacts of low intensity light on physiochemical and agronomic attributes of tobacco, to evaluate varying doses of foliar 5-aminolevulinic acid (5-ALA) for alleviation of adverse impacts of low light intensity and to observe either 5-ALA modulated physiochemical regulations impart stress tolerance at agronomic level. Significant decrease of biomass accumulation, synthesis of osmo-protectants, chlorophyll contents, and chlorophyll fluorescence and increase in malondialdehyde were recorded compared to control. Exogenous application of 5-ALA excellently alleviated adverse impacts of low light intensity stress on agronomic and physiochemical attributes of tobacco seedlings. Conclusively, Light stress had adverse implications on all studied attributes while 5-ALA at 10-20 $\mathrm{mg} / \mathrm{l}$ had remarkable alleviated deleterious impacts of light stress on plant.
\end{abstract}

\section{Introduction}

The productivity of crop is lagging far behind compared to its achievable potential because of low temperature and sunlight intensity at earlier stages of growth in Southwest China (Jiang et al. 2014). Coincidence of colder temperature and poor light intensity with early stages of development often leads to poor development of seedlings and ultimately deteriorates quality of tobacco leaves (Jin et al. 2014).

Low intensity of light hampers the electron flow in photosystem and thereby impair the biosynthesis of reductants at the end of light reactions (Yang et al. 2018). Consequences of poor efficacy of light reactions are limited availability of reductants and poor energy yields of light reactions (Li et al. 2018). Whereas, carbohydrates are prerequisites for growth slow down the growth rate and biomass accumulation (Townsend et al. 2018). Likewise, decrease in fluorescence of chlorophyll also decreases energy output of light reactions and eventually affect growth (Gao et al. 2018).

Stress conditions can be alleviated using numerous agronomic stratagems like plant growth substances. Among them, 5- aminolaevulinic acid (5-ALA) is a potent regulator of growth, enzymes, precursor in biosynthesis of chlorophyll and numerous physio-morphological attributes (Niu and Ma 2018). Exogenously applied 5-ALA enhances the synthesis of antioxidants, chlorophyll, soluble proteins and photosynthetic efficacy which impart stress tolerance (Farid et al. 2018).

*Author for correspondence: <wangsg@swu.edu.cn>. ${ }^{1}$ Chongqing Tobacco Science Research Institute, Chongqing, 400715, China. ${ }^{2}$ Department of Agronomy, University of Agriculture, Faisalabad 38040, Pakistan. ${ }^{3}$ Agronomic Research Station, Bahawalpur 63100, Pakistan. ${ }^{4}$ Pesticide Quality Control Laboratory, Bahawalpur 63100, Pakistan. 
Information about the adverse impacts of low light intensity to tobacco is scarce in previous studies. While, little is known about the 5-ALA modulated physiochemical regulations in tobacco since most of aforementioned studies have been conducted on other crops. Hence the present study was conducted to investigate adverse impacts of low light intensity in tobacco using physiochemical and morphological attributes as indicators, to optimize the exogenous 5-ALA as potent alleviator of adverse implications of low light on tobacco and to explore either 5-ALA mediated physiochemical transformations induce stress tolerance at morphological level.

\section{Materials and Methods}

The experiment was conducted at College of Agronomy and Biotechnology, Southwest

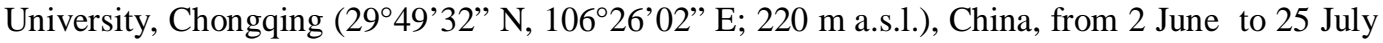
2016. Tobacco (Nicotiana tabacum K326) seedlings were grown in Petri plates, and treatments were applied after 40 days when the seedlings were with 5 functional leaves. The experiment was carried out in the greenhouse incubator $\left(12 \mathrm{hrs}\right.$ light $/ 25^{\circ} \mathrm{C}$; dark $12 \mathrm{hrs} / 16{ }^{\circ} \mathrm{C}$; intensity of illumination $200 \mu \mathrm{mol} \mathrm{m}^{-2} \mathrm{~s}^{-1}$; low light stress was the intensity of illumination $100 \mu \mathrm{mol} \mathrm{m}^{-2} \mathrm{~s}^{-1}$.). 5-ALA was foliar applied at 5 different concentrations. Treatments were comprised of $\mathrm{A}=$ intensity of illumination $200 \mu \mathrm{mol} \mathrm{m}^{-2} \mathrm{~s}^{-1}+$ distilled water (control); A0 $=$ Light stress + distilled water; A5 $=$ Light stress $+5 \mathrm{mg} / 1$ 5-ALA; A10 = Light stress $+10 \mathrm{mg} / \mathrm{l}$ 5-ALA; A20 = Light stress $+20 \mathrm{mg} / \mathrm{l}$ 5-ALA; A $40=$ Light stress $+40 \mathrm{mg} / 1$ 5-ALA and A80 = Light stress $+80 \mathrm{mg} / 1$ 5ALA. Whereas, foliar treatments were carried out on plants, second and third spray was applied again after 3 days interval to exploit full potential of application.

The experiment was conducted in CRD and replicated 3 times. Data were analyzed by ANOVA using the SPSS software (SPSS, version 25.0; IBM Corporation, Armonk, New York, USA) (Steel et al. 1997).

After measuring the height and fresh weight the seedling was placed in oven at $105^{\circ} \mathrm{C}$ for 20 min to stop respiration, followed by drying at $70^{\circ} \mathrm{C}$ for $48 \mathrm{hrs}$ to determine the dry weight. The malondialdehyde (MDA) content was assayed through thiobarbituric acid (TBA) assay (De-Vos et al. 1991). Free proline content was measured using the ninhydrin method (Bates et al. 1973). Soluble protein content was determined using coomassie brilliant blue method (Bradford 1976). Determination of soluble sugars was done by anthrone color method (Zhu et al. 2012). Chlorophyll and carotenoid content were measured using the method of Wellburn (1994). Fluorescence parameters were measured using a PAM-2000 portable pulsed modulation fluorometer (Quick and Stitt 1989, Van and Snel 1990).

\section{Results and Discussion}

Relatively lesser plant height was recorded under A80 $(3.50 \mathrm{~cm})$ compared to other treatments. While, higher and statistically similar plant height was observed in other treatments. Statistically similar and more stem diameter and dry weight were measured under A and A10 compared to other treatments. Whereas, statistically alike and higher fresh weight and root/shoot were recorded under A, A10 and A20 compared to other treatments. Contrarily, relatively lesser stem diameter, fresh and dry weight and root/shoot were recorded under A80 compared to other treatments (Table 1).

Statistically similar and significantly lesser synthesis of MDA was quantified under A10, A20, A40 and A80 compared to other treatments. While, statistically alike and more proline was recorded under $\mathrm{A}, \mathrm{A} 0$ and $\mathrm{A} 5$ compared to other treatments. Whereas, similar and more soluble proteins were observed under A, A5, A10, A20 and A40 compared to other treatments. Lesser 
synthesis of soluble sugars was observed under A0 while statistically similar and higher soluble sugars were quantified under all other treatments (Table 2).

Table 1. Effect of foliar 5-aminolevulinic acid on biomass accumulation of tobacco seedlings under low light intensity stress.

\begin{tabular}{lccccc}
\hline Treatments & Plant height $(\mathrm{cm})$ & $\begin{array}{c}\text { Stem diam } \\
(\mathrm{mm})\end{array}$ & $\begin{array}{c}\text { Fresh weight } \\
(\mathrm{g} / \text { plant })\end{array}$ & $\begin{array}{c}\text { Dry weight } \\
(\mathrm{g} / \text { plant })\end{array}$ & $\begin{array}{c}\text { Dry root/shoot } \\
\text { ratio }\end{array}$ \\
\hline $\mathrm{A}$ & $3.80 \pm 0.27 \mathrm{ab}$ & $3.69 \pm 0.22 \mathrm{a}$ & $2.92 \pm 0.20 \mathrm{a}$ & $0.14 \pm 0.01 \mathrm{a}$ & $0.12 \pm 0.01 \mathrm{a}$ \\
$\mathrm{A} 0$ & $3.94 \pm 1.01 \mathrm{ab}$ & $3.38 \pm 0.19 \mathrm{ab}$ & $2.16 \pm 0.48 \mathrm{bc}$ & $0.09 \pm 0.02 \mathrm{~b}$ & $0.08 \pm 0.00 \mathrm{bc}$ \\
$\mathrm{A} 5$ & $3.77 \pm 0.32 \mathrm{ab}$ & $3.12 \pm 0.08 \mathrm{~b}$ & $2.03 \pm 0.04 \mathrm{c}$ & $0.09 \pm 0.00 \mathrm{~b}$ & $0.08 \pm 0.01 \mathrm{c}$ \\
$\mathrm{A} 10$ & $4.72 \pm 0.39 \mathrm{a}$ & $3.72 \pm 0.20 \mathrm{a}$ & $2.87 \pm 0.33 \mathrm{ab}$ & $0.13 \pm 0.01 \mathrm{a}$ & $0.11 \pm 0.02 \mathrm{ab}$ \\
$\mathrm{A} 20$ & $4.13 \pm 0.71 \mathrm{ab}$ & $3.20 \pm 0.38 \mathrm{~b}$ & $2.22 \pm 0.70 \mathrm{abc}$ & $0.10 \pm 0.03 \mathrm{~b}$ & $0.10 \pm 0.02 \mathrm{abc}$ \\
$\mathrm{A} 40$ & $3.71 \pm 0.84 \mathrm{ab}$ & $3.17 \pm 0.40 \mathrm{~b}$ & $1.96 \pm 0.40 \mathrm{c}$ & $0.09 \pm 0.02 \mathrm{~b}$ & $0.08 \pm 0.00 \mathrm{c}$ \\
A80 & $3.50 \pm 0.28 \mathrm{~b}$ & $3.04 \pm 0.18 \mathrm{~b}$ & $1.73 \pm 0.16 \mathrm{c}$ & $0.08 \pm 0.01 \mathrm{~b}$ & $0.07 \pm 0.02 \mathrm{c}$ \\
\hline
\end{tabular}

Values are mean \pm SE. Values followed by different letters within each column are significantly different according to DMRT $(\mathrm{p}<0.05)$.

Table 2. Effect of foliar 5-aminolevulinic acid on membrane stability and osmo-protectants of tobacco seedlings under low light intensity stress.

\begin{tabular}{lcccc}
\hline Treatments & $\begin{array}{c}\text { MDA } \\
(\mathrm{nmol} / \mathrm{g})\end{array}$ & $\begin{array}{c}\text { Free proline } \\
(\mu \mathrm{g} / \mathrm{g})\end{array}$ & $\begin{array}{c}\text { Soluble protein } \\
(\mathrm{mg} / \mathrm{g})\end{array}$ & $\begin{array}{c}\text { Soluble sugars } \\
(\mathrm{mg} / \mathrm{g})\end{array}$ \\
\hline $\mathrm{A}$ & $6.21 \pm 2.00 \mathrm{a}$ & $41.34 \pm 14.83 \mathrm{a}$ & $8.21 \pm 1.03 \mathrm{a}$ & $3.16 \pm 0.98 \mathrm{ab}$ \\
$\mathrm{A} 0$ & $9.78 \pm 1.65 \mathrm{a}$ & $31.40 \pm 4.80 \mathrm{ab}$ & $6.33 \pm 0.35 \mathrm{~b}$ & $1.89 \pm 0.67 \mathrm{~b}$ \\
$\mathrm{~A} 5$ & $8.53 \pm 0.15 \mathrm{~b}$ & $28.53 \pm 5.06 \mathrm{ab}$ & $6.98 \pm 0.48 \mathrm{ab}$ & $2.38 \pm 0.94 \mathrm{ab}$ \\
$\mathrm{A} 10$ & $7.38 \pm 2.24 \mathrm{c}$ & $25.41 \pm 6.30 \mathrm{~b}$ & $6.77 \pm 0.27 \mathrm{ab}$ & $2.68 \pm 0.88 \mathrm{ab}$ \\
$\mathrm{A} 20$ & $7.03 \pm 1.59 \mathrm{c}$ & $11.31 \pm 9.06 \mathrm{c}$ & $7.04 \pm 1.49 \mathrm{ab}$ & $4.11 \pm 1.43 \mathrm{a}$ \\
$\mathrm{A} 40$ & $7.85 \pm 0.81 \mathrm{c}$ & $7.66 \pm 3.77 \mathrm{~d}$ & $7.10 \pm 1.22 \mathrm{ab}$ & $2.68 \pm 0.95 \mathrm{ab}$ \\
$\mathrm{A} 80$ & $7.76 \pm 1.21 \mathrm{c}$ & $19.64 \pm 5.11 \mathrm{bc}$ & $2.10 \pm 0.53 \mathrm{c}$ & $2.39 \pm 0.31 \mathrm{ab}$ \\
\hline
\end{tabular}

Statistically similar and more chlorophyll $a$ was recorded under A, A10, A40 and A80 compared to other treatments. Whereas, statistically alike and higher biosynthesis of chlorophyll $b$ and carotenoids were observed under A0, A40 and A80. While, almost similar and higher chlorophyll $a / b$ were quantified under other treatments compared to A0 (Table 3).

Statistically alike and more minimum fluorescence (F0) was observed under A, A5, A10 and A80 compared to other treatments. While, significantly higher maximum fluorescence (Fm), minimum fluorescence after $5 \mathrm{~min}\left(\mathrm{FO}^{\prime}\right)$ and maximum fluorescence after $5 \mathrm{~min}$ (Fm') were recorded under A compared to other treatments. Likewise, statistically similar and more photochemical efficiency $(\mathrm{Fv} / \mathrm{Fm})$ was quantified under $\mathrm{A}, \mathrm{A} 40$ and $\mathrm{A} 80$ compared to other treatments (Table 4).

Improvement of biomass accumulation under light stress and exogenous 5-ALA can be attributed to its role in biosynthesis of chlorophyll. Improvement of chlorophyll contents might have enhanced the synthesis of carbohydrates and more partitioning of carbohydrates towards 
green parts resulted in accumulation of biomass. However, biomass accumulation did not enhance linearly with increasing concentrations of exogenous 5-ALA. It can be ascribed to inhibitory effect at higher concentrations. Moreover, poor accumulation of biomass at higher concentrations of 5-ALA can be defined in context of higher MDA and lesser synthesis of osmo-protectants. Light stress might have slowed down the synthesis of osmo-protectants which ultimately aggravated oxidative stress and therefore slowed the accumulation of biomass. Application of 5-ALA enhanced the synthesis of osmo-protectants and biomass accumulation under stress conditions (Xiong et al. 2018).

Table 3. Effect of foliar 5-aminolevulinic acid on stay green trait of tobacco seedlings under low light intensity stress.

\begin{tabular}{llllll}
\hline Treatments & $\begin{array}{l}\text { Chl } a \\
(\mathrm{mg} / \mathrm{g})\end{array}$ & $\begin{array}{l}\mathrm{Chl} b \\
(\mathrm{mg} / \mathrm{g})\end{array}$ & $\begin{array}{l}\text { Carotenoid } \\
(\mathrm{mg} / \mathrm{g})\end{array}$ & $\begin{array}{l}\text { Total chlorophyll } \\
(\mathrm{mg} / \mathrm{g})\end{array}$ & Chl $\mathrm{a} / \mathrm{b}$ \\
\hline $\mathrm{A}$ & $1.05 \pm 0.30 \mathrm{ab}$ & $0.41 \pm 0.11 \mathrm{~b}$ & $0.14 \pm 0.04 \mathrm{~d}$ & $1.56 \pm 0.42 \mathrm{ab}$ & $2.56 \pm 0.07 \mathrm{ab}$ \\
$\mathrm{A} 0$ & $0.94 \pm 0.14 \mathrm{~b}$ & $0.49 \pm 0.06 \mathrm{ab}$ & $0.23 \pm 0.03 \mathrm{a}$ & $1.43 \pm 0.21 \mathrm{ab}$ & $1.91 \pm 0.01 \mathrm{~b}$ \\
$\mathrm{~A} 5$ & $0.99 \pm 0.06 \mathrm{~b}$ & $0.38 \pm 0.02 \mathrm{~b}$ & $0.17 \pm 0.01 \mathrm{~cd}$ & $1.37 \pm 0.08 \mathrm{~b}$ & $2.61 \pm 0.04 \mathrm{a}$ \\
$\mathrm{A} 10$ & $1.04 \pm 0.11 \mathrm{ab}$ & $0.41 \pm 0.04 \mathrm{~b}$ & $0.18 \pm 0.03 \mathrm{bc}$ & $1.45 \pm 0.16 \mathrm{ab}$ & $2.54 \pm 0.02 \mathrm{ab}$ \\
A20 & $1.06 \pm 0.03 \mathrm{~b}$ & $0.38 \pm 0.02 \mathrm{~b}$ & $0.18 \pm 0.01 \mathrm{bc}$ & $1.44 \pm 0.05 \mathrm{~b}$ & $2.79 \pm 0.04 \mathrm{a}$ \\
A40 & $1.32 \pm 0.07 \mathrm{a}$ & $0.53 \pm 0.04 \mathrm{a}$ & $0.23 \pm 0.02 \mathrm{a}$ & $1.85 \pm 0.12 \mathrm{a}$ & $2.49 \pm 0.03 \mathrm{ab}$ \\
$\mathrm{A} 80$ & $1.22 \pm 0.19 \mathrm{a}$ & $0.49 \pm 0.09 \mathrm{ab}$ & $0.22 \pm 0.02 \mathrm{ab}$ & $1.71 \pm 0.31 \mathrm{ab}$ & $2.49 \pm 0.10 \mathrm{ab}$ \\
\hline
\end{tabular}

Table 4. Effect of foliar 5-aminolevulinic acid on chlorophyll fluorescence of tobacco seedlings under low light intensity stress.

\begin{tabular}{lccccc}
\hline Treatments & F0 & Fm & FV/Fm & F0' & Fm $^{\prime}$ \\
\hline A & $377.50 \pm 27.58 \mathrm{ab}$ & $2098.00 \pm 19.80 \mathrm{a}$ & $0.82 \pm 0.01 \mathrm{a}$ & $340.00 \pm 21.21 \mathrm{a}$ & $1301.50 \pm 13.44 \mathrm{a}$ \\
A0 & $363.50 \pm 26.16 \mathrm{~b}$ & $1497.00 \pm 118.79 \mathrm{c}$ & $0.76 \pm 0.00 \mathrm{bc}$ & $276.00 \pm 8.49 \mathrm{bc}$ & $651.50 \pm 13.44 \mathrm{bc}$ \\
A5 & $425.00 \pm 25.46 \mathrm{a}$ & $1498.50 \pm 178.90 \mathrm{c}$ & $0.71 \pm 0.05 \mathrm{c}$ & $309.50 \pm 19.09 \mathrm{ab}$ & $645.50 \pm 9.19 \mathrm{bc}$ \\
A10 & $387.00 \pm 1.41 \mathrm{ab}$ & $1594.50 \pm 86.97 \mathrm{bc}$ & $0.76 \pm 0.01 \mathrm{bc}$ & $280.00 \pm 8.49 \mathrm{bc}$ & $622.00 \pm 60.81 \mathrm{bc}$ \\
A20 & $358.00 \pm 0.00 \mathrm{~b}$ & $1532.00 \pm 22.63 \mathrm{c}$ & $0.77 \pm 0.00 \mathrm{~b}$ & $259.00 \pm 9.90 \mathrm{c}$ & $584.00 \pm 55.15 \mathrm{c}$ \\
A40 & $344.50 \pm 19.09 \mathrm{~b}$ & $1549.00 \pm 62.23 \mathrm{bc}$ & $0.78 \pm 0.00 \mathrm{ab}$ & $260.50 \pm 24.75 \mathrm{c}$ & $631.50 \pm 92.63 \mathrm{bc}$ \\
A80 & $390.00 \pm 12.73 \mathrm{ab}$ & $1765.00 \pm 29.70 \mathrm{~b}$ & $0.78 \pm 0.00 \mathrm{ab}$ & $298.50 \pm 16.26 \mathrm{bc}$ & $739.00 \pm 62.23 \mathrm{~b}$ \\
\hline
\end{tabular}

F0 = Minimum fluorescence; Fm = Maximum fluorescence $; \mathrm{Fv} / \mathrm{Fm}=$ Photochemical efficiency;

F0' = minimum fluorescence after 5 min; Fm' = Maximum fluorescence after 5 min.

Light stress might promote the synthesis of reactive oxygen species which ultimately triggered lipid peroxidation of membranes. Hence, capability of cells to retain water might have decreased and consequently growth was slowed down. Moreover, light stress might have triggered the breakdown of chlorophyll. Accelerated breakdown of chlorophyll might decrease the availability of carbon skeleton which is prerequisite for synthesis of proline, soluble proteins and soluble sugars (Shahid et al. 2017). Moreover, stress triggered disruptions in physiochemical attributes decided strong correlation with morphological attributes and thus negative impacts were recorded at agronomic level also (Saleem et al. 2017). 
Application of 5-ALA enhanced net photosynthetic rate, photochemical quenching and photosynthetic activity of leaf based on the electron transport rate of photosystem-II, ultimately tolerance against stress conditions was improved (Niu and Ma 2018). Likewise, foliar applied 5-ALA enhanced activities of antioxidants, synthesis of chlorophyll and decreased leakage of electrolytes under stress conditions (Farid et al. 2018).

Improvements in biosynthesis of chlorophyll, fluorescence and quantum yield of photosynthesis can be attributed to 5-ALA mediated boost in activities of protochlorophyllide. Upregulations in synthesis of protochlorophyllide might have acted as substrate for synthesis of chlorophyll and consequence in improvements of chlorophyll contents. Foliar application of 5ALA inhibited the synthesis of aminolaevulinic acid dehydratase and porphobilinogen deaminase which decreased the degradation of chlorophyll (Hemantaranjan et al. 2014). Likewise, improvements in fluorescence of chlorophyll and quantum yield of photosynthesis under availability of 5-ALA can also be attributed to antioxidative and protective action of proline, soluble sugars and proteins. Accumulation of osmo-protectants under availability of 5-ALA might have enhanced the solute concentration and thus reduced the sensitivity towards light intensity. Exogenous application of 5-ALA under stress conditions improved accumulation of osmoprotectants, net photosynthetic rate and stomatal conductance (Kosar et al. 2014). While application of 5-ALA enhanced the biosynthesis of chlorophyll under stress environments (Feng et al. 2015). Likewise, availability of 5-ALA under stress improved carbon fixation, decreased photoinhibition and osmotic stress (Niu and Ma 2018).

The results of the present study revealed that imposition of light stress deleteriously impacted biomass accumulation, membrane stability, synthesis of osmo-protectants, chlorophyll contents, and chlorophyll fluorescence in tobacco seedling, while exogenously applied 5-ALA effectively alleviated adverse implications of light stress on these attributes. More remarkable agronomic, biochemical and physiochemical responses were recorded with $10-20 \mathrm{mg} / \mathrm{l}$ exogenous 5-ALA under light stress.

\section{Acknowledgements}

The authors are grateful to the authorities of Chongqing Tobacco Company Research Program of China (CYK-NY20170403050005 and CYK-NY20150601070011) along with Crop Germplasm Resources Utilization and Innovation Base Program of the 111 Project of China (104510-205001).

\section{References}

Bates LS, RP Waldren, and ID Teare 1973. Rapid determination of free proline for water-stress studies. Plant and Soil 39: 205-207.

Bradford MN 1976. A rapid and sensitive method for the quantitation of microgram quantities of protein utilizing the principle of protein-dye binding. Analytical Biochemistry 72: 248-254.

De-Vos C, HM Schat, MAD Waal, R Vooijs and W Ernst 1991. Increased resistance to copper-induced damage of the root plasma membrane in copper tolerant Silene cucubalus. Physiologia. Plantarum 82: 523-528.

Farid M, Shafaqat A, Muhammad R, Qasim A, Rashid S, Tauqir N, Ghulam HA, Muhammad IAR, Syed TA, Syed AHB, and Tanvir A 2018. Phyto-management of chromium contaminated soils through sunflower under exogenously applied 5-aminolevulinic acid. Ecotoxicology and Environmental Safety 151: 255-265.

Feng S, M Li, F Wu, W Li, and S Li 2015. 5-Aminolevulinic acid affects fruit coloration, growth, and nutrition quality of Litchi chinensis Sonn. cv. Feizixiao in Hainan, tropical China. Scientia Horticulturae 193:188-194. 
Gao H, Zong X, Lu J, Xu Y, He X Dong Y, Zhang Y, and Wang S 2018. Photosynthetic physiology changes of rice in combined high temperature and drought stress at grain-filling stage. Ecology and Environmental Monitoring of Three Gorges 3(2): 68-76.

Hemantaranjan A, AN Bhanu, MN Singh, DK Yadav, PK Patel, R Singh and D. Katiyar 2014. Heat stress responses and thermotolerance. Adv. Plants Agric. Res. 1(3): 00012. doi: 10.15406/apar.2014.01.00012.

Jiang H, Li N, Xu A, Yang C, Wang H, Chen H, Shan P, and Ding W 2014. Development of closed-type transplant production system and discussion of its application mode for flue-cured tobacco. Australian Journal of Crop Science 8: 1566-1570.

Jin X, Tian BW and Chen FL 2014. Comparative study on intensive three-dimensional breeding and floating seedling raising of flue-cured tobacco. J. Henan Agric. Sci. 43(5): 62-65.

Kosar F, NA Akram, and M Ashraf 2014. Exogenously-applied 5-aminolevulinic acid modulates some key physiological characteristics and antioxidative defense system in spring wheat (Triticum aestivum L.) seedlings under water stress. South Afr. J. Bot. 96: 71-77.

Li L, Eva-Mari A, and AH Millar 2018. Mechanisms of photodamage and protein turnover in photoinhibition. Trends in Plant Science 23: 667-676.

Niu K, and H Ma 2018. The positive effects of exogenous 5-aminolevulinic acid on the chlorophyll biosynthesis, photosystem and calvin cycle of Kentucky bluegrass seedlings in response to osmotic stress. Environmental and Experimental Botany 155: 260-271.

Quick WP and Stitt M 1989. An examination of factors contributing to nonphoto -chemical quenching of chlorophyll fluorescence in barley leaves. Biochim. Biophys. Acta 977: 287-296.

Saleem MF, Muhammad AK, SA Anjum, Muhammad S, Muhammad ASR and Muhammad A 2018. Improvingthe performance of Bt-cotton under heat stress by foliar application of selenium, Journal of Plant Nutrition 41: 1711-1723.

Shahid M, MF Saleem, SA Anjum, M Shahid, and I Afzal 2017. Biochemical markers assisted screening of Pakistani wheat (Triticum aestivum L.) cultivars for terminal heat stress tolerance. Pak. J. Agric. Sci. 54(4): $837-845$.

Townsend AJ, Francesco S, Vasco G, Sam W, Petra U, and Alexander VR 2018. The causes of altered chlorophyll fluorescence quenching induction in the Arabidopsis mutant lacking all minor antenna complexes. Biochimica et Biophysica Acta - Bioenergetics 1859: 666-675.

Van Kooten O and Snel JFH ,1990. The use of chlorophyll fluorescence nomenclature in plant stress physiology. Photosynth. Res. 25:147-150

Wellburn AR 1994. The spectral determination of chlorophyll-a and chlorophyll-b, as well as total carotenoids, using various solvents with spectrophotometers of different resolution. J. Plant Physiol. 144: 307-313.

Xiong JL, H Wang, X Tan, C Zhang, and Muhammad SN 2018. 5-aminolevulinic acid improves salt tolerance mediated by regulation of tetrapyrrole and proline metabolism in Brassica napus L. seedlings under $\mathrm{NaCl}$ stress. Plant Physiol. and Biochem. 124: 88-99.

Yang F, L Feng, Q Liu, X Wu, Y Fan, Muhammad AR, Y Cheng, J Chen, X Wang, T Yong, W Liu, J Liu, J $\mathrm{Du}, \mathrm{K} \mathrm{Shu}$, and W Yang 2018. Effect of interactions between light intensity and red-to- far-red ratio on the photosynthesis of soybean leaves under shade condition. Environmental and Experimental Botany 150: $79-87$

Zhu WZ, M Cao, SG Wang, WF Xiao and MH Li 2012. Seasonal dynamics of mobile carbon supply in Quercus aquifolioides at the upper elevational limit. PLoS One 7: 1-11.

(Manuscript received on 2 September, 2018; revised on 28 December, 2018) 